\title{
FAKTOR DETERMINAN KEJADIAN BACTERIAL VAGINOSIS (BV) DI KABUPATEN BANDUNG
}

\author{
Rosita \\ Program Studi Diploma Kebidanan STIKes Dharma Husada \\ rositasdhb@gmail.com
}

\begin{abstract}
ABSTRAK
Bacterial vaginosis (BV) merupakan kondisi ketidak seimbangan dari ekosistem vagina, yaitu menurunnya jumlah Lactobacillus yang diikuti dengan peningkatan jumlah Gardnerella vaginalis dan kuman anaerob lainnya. BV biasanya tidak bergejala, namun ketika menimbulkan gejala biasanya disertai dengan keputihan yang berbau. Penelitian ini menggunakan desain penelitian kuantitatif deskriptif dengan pendekatan Analisis Data Sekunder. Sample yang digunakan dalam penelitian ini adalah seluruh pasien atau WUS yang terdata atau tercatat dalam laporan di wilayah Kabupaten Bandung yaitu sebanyak 83 orang.

Hasil penelitian menunjukan dari 83 WUS yang dilakukan pemeriksaan, sebanyak 4 orang yang merokok dan 1 orang yang positif BV dengan $\mathrm{p}$ Value 1,10. Dalam hal ini secara statistik tidak menunjukan adanya pengaruh merokok dengan kejadian BV. Sedangkan untuk aktivitas seksual secara statistik menunjukan bahwa $\mathrm{p}$ Value 0,010 maka terdapat pengaruh yang signifikan antara aktifitas seksual secara aktif dengan kejadian BV. Pada faktor penggunaan cairan pencuci vagina menunjukan dengan $p$ Value 0,012 maka secara statistik menunjukan bahwa terdapat pengaruh antara penggunaan cairan pencuci vagina dengan kejadian BV. Sedangkan yang terakhir secara statistik menjukan $\mathrm{p}$ Value 0,012 maka dapat terlihat bahwa terdapat pengaruh yang bermakna antara penggunaan alat kontrasepsi dengan kejadian BV.

Diharapkan masyarakat dapat mengetahui tanda gejala BV secara dini dan menghindari faktor-faktor yang dapat memperberat kejadian BV. Dan petugas kesehatan dapat melakukan screening secara dini terutama pada wus yang mempunyai faktor risiko.
\end{abstract}

Kata Kunci : Faktor Determinan, Bacterial Vaginosis (BV).

\section{PENDAHULUAN}

Bacterial vaginosis (BV) merupakan kondisi ketidak seimbangan dari ekosistem vagina, yaitu menurunnya jumlah Lactobacillus yang diikuti dengan peningkatan jumlah Gardnerella vaginalis dan kuman anaerob lainnya. ${ }^{1}$ BV biasanya tidak bergejala, namun ketika menimbulkan gejala biasanya disertai dengan keputihan yang berbau. ${ }^{2}$ Angka kejadian BV di negara-negara berkembang tidak jauh berbeda. Penelitian di New Delhi,
India menemukan $32,8 \%$ kasus BV dengan $31,2 \%$ diantaranya asimtomatis. BV juga ditemukan pada 10-20\% wanita aktif seksual serta dengan prevalensi lebih tinggi pada wanita dengan Infeksi Menular Seksual (IMS) yang mengunjungi klinik spesialis. ${ }^{5}$

Prevalensi kejadian BV di seluruh dunia terbilang cukup tinggi. Prevalensi bervariasi pada populasi wanita misalnya pada wanita hamil, remaja, Wanita Pekerja Seks (WPS), HIV positif. Pada tahun 2001-2004 di Amerika 
Serikat dilakukan National Health and Nutrition Examination Survey (NHANES) dan didapatkan hasil prevalensi BV sebesar 29,2\% yang setara dengan 21 juta wanita, penelitian pada ibu hamil $28,1 \%$, dikalangan remaja $20 \%$, perempuan HIV-positif $36 \%$, sedangkan pada WPS lebih tinggi yaitu $62,9 \%{ }^{6}$

Pada tahun 2005 di Jakarta prevalensi infeksi saluran reproduksi yang terjadi yaitu candidiasis $6,7 \%$, tricomoniasis $5,4 \%$ dan bacterial vaginosis $5,1 \%$. Menurut data tahun 2007 di Indonesia prevalensi infeksi saluran reproduksi sebanyak bacterial vaginosis $53 \%$ dan vaginal kandidiasis 3\%. Tahun 2008 prevalensi infeksi saluran reproduksi pada remaja putri dan wanita dewaa yang disebabkan oleh bacterial vaginosis sebesar $46 \%$, candida albicans $29 \%$ dan tricomoniasis $12 \%$. Infeksi bakteri sekalipun hanya vagina BV harus disembuhkan karena dapat menimbulkan infeksi pada organ reproduksi yang lain. Strategi pencegahan dibutuhkan untuk mengurangi insiden BV dengan identifikasi faktor risiko yang merupakan upara preventif. $^{8,9}$

Infeksi BV yang ditandai dengan sekret vagina paling sering muncul pada masa reproduksi (reproductive age). ${ }^{9} \quad$ Angka prevalensi infeksi BV pada ibu hamil cukup banyak, yaitu berkisar $13-31 \% .^{10}$ The Vaginal Infections and Prematurity Study Group juga telah mengidentifikasi infeksi BV sebesar $16 \%$ dari 1.000 ibu hamil pada usia kehamilan 23-26 minggu. ${ }^{11}$ Angka prevalensi infeksi BV di Indonesia cukup besar pada kelompok umur
41-45 tahun (54,5\%), mahasiswa/pelajar $(45,7 \%)$ dan paritas $>5(50 \%) .{ }^{5}$ Selain itu pada wanita hamil di RSUP Dr Kariadi Semarang didapatkan sebesar $43,3 \%$ terdiagnosa infeksi BV dan $38,5 \%$ tidak mengeluhkan adanya gejala.

Seseorang memiliki peluang lebih besar menderita vaginosis bakteri bila melakukan irigasi vagina, atau seringkali membersihkan vagina dengan sabun dan produk lain. Terdapat peningkatan 9,3\% wanita dari BV negatif menjadi positif setelah satu bulan pemasangan IUD atau AKDR. Di Kabupaten bandung sendiri terdapat 714.046 PUS yang aktif menggunakan alat kontrasepsi, dan IUD merupakan alat kontrasepsi kedua paling banyak penggunanya setelah suntik. ${ }^{13}$

Penelitian ini bertujuan untuk mengetahui faktor determinan diantaranya faktor merokok, aktifitas seksual, cairan pencuci vagina dam penggunaan alat kontrasepsi seksual terhadap kejadian BV.

\section{METODE PELAKSANAAN}

Penelitian ini menggunakan desain penelitian kunatitatif deskriptif dengan pendekatan analisis data sekunder. Dalam penelitian ini data diperoleh dari dinas kesehatan Kabupaten Bandung. Hal ini diharapkan data ini tentu kemudian diolah secara sistematis dan objektif. Sampel yang digunakan adalah seluruh pasien yang bersedia dan menandatangani inform concent untuk pengambilan secret sebagai upaya penapisan BV. Variabel dependen dalam penelitian ini 
adalah hasil pemeriksaan apakah positif BV atau non BV. Variabel independen adalah wanita usia subur yang merokok, aktifitas seksual, penggunaan cairan vagina dan penggunaan alat kontrasepsi dengano menggunakan skala ukur nominal. Analisa data dilakukan menggunakan software program komputer untuk melihat hasil analisis univariat dan analisis bivariat.

\section{HASIL DAN PEMBAHASAN a. Hasil}

Tabel 1 Distribusi Frekuensi gambaran faktor determinan WUS terhadap kejadian BV

\begin{tabular}{|c|c|c|c|}
\hline & Aktivitas & $\mathbf{F}$ & $\%$ \\
\hline \multicolumn{4}{|c|}{ Merokok pada WUS } \\
\hline 1. & Tidak Merokok & 79 & $95,3 \%$ \\
\hline 2. & Merokok & 4 & $4,8 \%$ \\
\hline \multicolumn{4}{|c|}{ Seksual pada WUS } \\
\hline & Tidak Aktif & 0 & $0 \%$ \\
\hline & Aktif & 83 & $100 \%$ \\
\hline \multicolumn{4}{|c|}{$\begin{array}{l}\text { Penggunaan cairan pencuci } \\
\text { vagina pada WUS }\end{array}$} \\
\hline 1. & Tidak Menggunakan & 53 & $74,8 \%$ \\
\hline 2. & Menggunakan & 30 & $25,2 \%$ \\
\hline \multicolumn{4}{|c|}{$\begin{array}{l}\text { Penggunaan alat } \\
\text { kontrasepsi pada WUS }\end{array}$} \\
\hline 1. & Tidak menggunakan & 0 & $0 \%$ \\
\hline 2. & Pil & 2 & $2,4 \%$ \\
\hline 3. & Suntik & 50 & $60,25 \%$ \\
\hline 5. & Implan & 0 & $0 \%$ \\
\hline 6. & Kondom & 0 & $0 \%$ \\
\hline 7. & MOW & 0 & $0 \%$ \\
\hline
\end{tabular}

Berdasarkan tabel 1, aktivitas WUS terhadap kejadian BV yang paling banyak adalah Tidak merokok (95,3\%), aktif seksual (100\%), Tidak menggunakan cairan pencuci vagina $(74,8 \%)$, penggunaan kontrasepsi suntik $(60,25 \%)$
Tabel 2 Distribusi Frekuensi pengaruh faktor determinan WUS terhadap kejadian BV

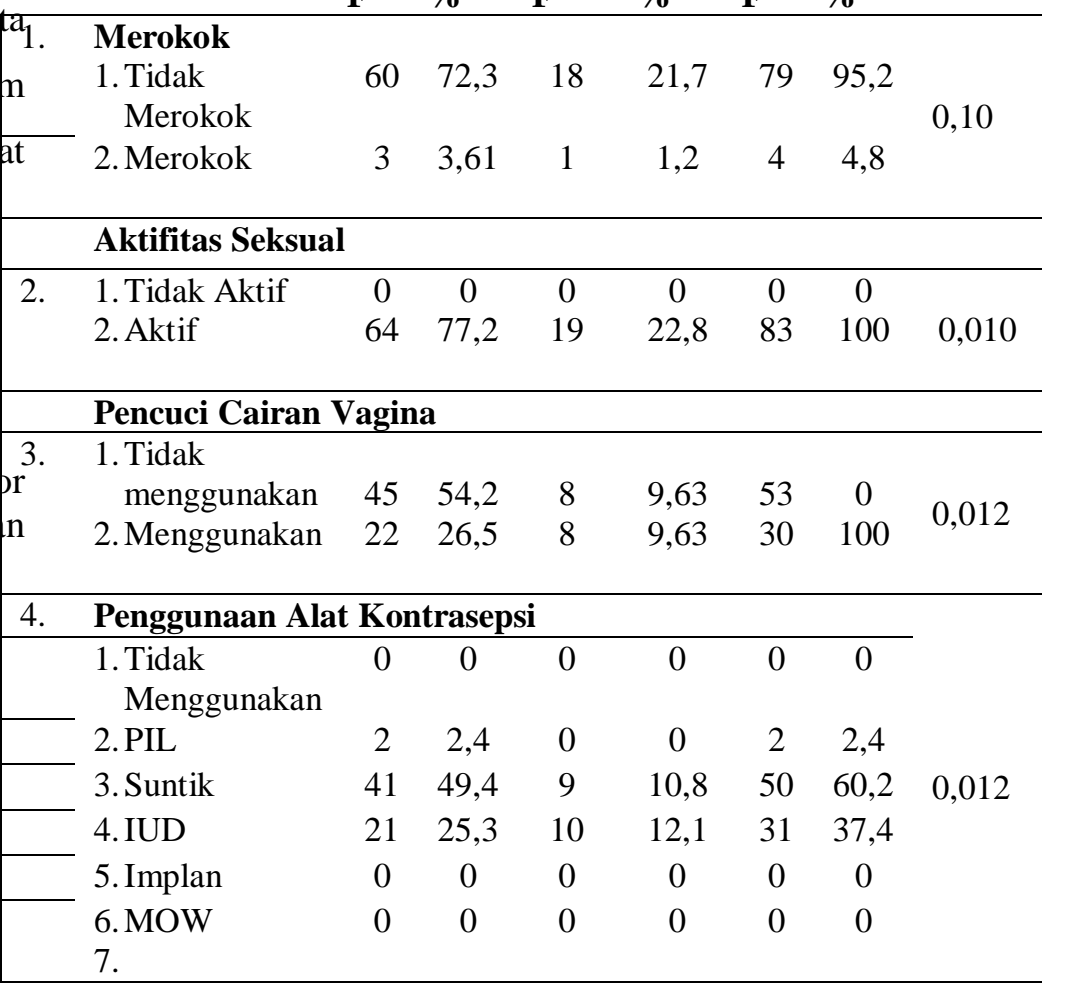

\section{b. Pembahasan}

BV sering dikaitkan pula dengan pasangan seksual multipel pria atau wanita, pasangan seksual baru, dan tidak adanya penggunaan kondom. ${ }^{3,8}$ Ociviyanti dan kawan-kawan melaporkan pasangan seksual yang tidak dilakukan sirkumsisi merupakan faktor risiko terjadinya BV. ${ }^{13}$ Sirkumsisi dikaitkan dengan higienitas penis yang dihubungkan dengan transmisi infeksi. Hal itu karena membran mukosa preputium lebih rentan terhadap trauma dan menjadi jalan masuk bakteri patogen. ${ }^{8,17}$ 
Berbagai penelitian telah menunjukan bahwa pengobatan untuk laki-laki pasangan seksual pasien BV ternyata tidak mengurangi angka kesembuhan, sehingga tidak dianjurkan untuk mengobati laki-laki pasangan seksual pasien BV. Respons pasien terhadap terapi ataupun rekurensi tidak dipengaruhi oleh terapi pada pasangan seksual. Ketidaksesuaian antara data yang menunjukan penularan BV melalui hubungan seksual dengan ketiadaan manfaat pengobatan lakilaki pasangan seksual, masih menimbulkan pertanyaan sampai saat ini. ${ }^{7,8,17}$

Wanita memiliki masalah pada area vagina seperti infeksi vagina yang disebabkan oleh hubungan seks, minum antibiotika dalam waktu yang lama, penggunaan sabun dengan $\mathrm{pH}$ yang tidak sesuai sehingga menimbulkan keputihan. ${ }^{1}$ Salah satu upaya untuk mencegah keputihan adalah melakukan perawatan wanita yang disebut bilas vagina. ${ }^{1}$ American College of Obstetricians and Gynecologist (ACOG) menyarankan wanita sebaiknya menghindari melakukan douching. ${ }^{2}$ Penelitian 3 mengatakan bahwa 2 produk cairan bilas vagina terbukti menghambat pertumbuhan flora baik pada vagina sehingga akan menganggu fungsi normal vagina. ${ }^{3}$

Penelitian di Kota Magelang menunjukkan 18 wanita usia subur mengatakan bahwa bilas vagina sangat penting dilakukan agar terhindar dari bakteri serta tejaga kebersihannya. Sebanyak 17 orang $(94,4 \%)$ melakukan bilas vagina menggunakan air biasa dengan air rebusan daun sirih $(50 \%)$, air biasa $(22 \%)$, sabun mandi $(11 \%)$, cairan pembersih vagina tersebut (6\%). Praktik tersebut dilakukan setelah melakukan hubungan intim (29\%), mengurangi bau vagina dan membuat kesat (39\%), membilas darah haid setelah selesai mentruasi (10\%) dan mengurangi keputihan (22\%). Bilas vagina (vaginal douching) dikaitkan dengan masalah kesehatan pada wanita karena bilas vagina merusak flora normal dalam vagina sehingga memberikan risiko tumbuhnya bakteri vaginosis $(\mathrm{BV}){ }^{4}$

Ketidakseimbangan $\quad \mathrm{pH}$ vagina mengakibatkan tumbuhnya jamur dan kumankuman yang lain. Adanya flora normal dibutuhkan untuk menekan tumbuhan yang lain itu untuk tidak tumbuh subur. Jika keasaman dalam vagina berubah maka kumankuman lain dengan mudah akan tumbuh sehingga akibatnya bisa terjadi infeksi yang akhirnya menyebabkan keputihan, yang berbau, gatal, dan menimbulkan ketidaknyamanan. ${ }^{5}$ Terdapat beberapa faktor yang dapat mempengaruhi seseorang melakuan tindakan vaginal douching. Perilaku individu dalam memutuskan tindakan kesehatan dipengaruhi oleh pandangan / persepsi dirinya terhadap perilaku tersebut tanpa memperdulikan pandangan tersebut sesuai atau tidak dengan kenyataan. praktik vaginal douching dilakukan karena banyak manfaatnya seperti untuk kebersihan vagina, pencegahan infeksi genital, membersihkan darah haid, membersihkan sebelum melakukan hubungan suami istri, pencegahan keputihan, penurunan bau tidak sedap pada vagina serta keyakinan agama tertentu. $^{7}$ 
Ada berbagai penelitian mengatakan banyak wanita berpendapat jika douching perlu dilakukan agar kebersihan vagina terjaga. Menurut 3 praktik vaginal douching justru memberikan efek merugikan untuk flora baik pada vagina. Bilas vagina mengakibatkan terjadinya perubahan keseimbangan kimiawi dan flora vagina, sehingga wanita mempunyai faktor resiko terhadap infeksi bakteri. Selain itu douching juga bisa menyebarkan infeksi vaginal atau servikal yang sudah menyebar ke arah atas menuju organ-organ panggul (uterus, tuba fallopi, dan ovarium). Hasil dari suatu penelitian menunjukkan bahwa perempuan yang melakukan douching vaginal secara rutin cenderung mengalami iritasi vagina. Sebagian dari subyek penelitian merasa bahwa praktik vaginal douching bermanfaat untuk menjaga organ kewanitaan. ${ }^{3}$

Praktik vaginal douching dapat mencegah infeksi menular seksual, membersihkan vagina dari sisa haid, membuat vagina wangi dan kesat, mencegah keputihan dan membuat hubungan suami istri menjadi lebih puas. Persepsi pemahaman yang salah dan persepsi yang rendah akan risiko kesehatan tetang vaginal douching mempengaruhi seseorang melakukan praktik tersebut. Persepsi hambatan berhubungan dengan praktik vaginal douching pada wanita usia subur di Kelurahan Gelangan secara signifikan dan menunjukkan nilai koefisien negatif dimana ketika subyek merasakan hambatan/ kesulitan yang rendah untuk melakukan praktik vaginal douching maka praktik vaginal douching akan dilakukan.
Apabila hambatan untuk melakukan praktik vaginal douching tinggi, maka praktik tersebut akan lebih sulit untuk dilakukan.

Hambatan umum yang dialami seseorang dalam menentukan tindakan kesehatan atau memanfaatkan pelayanan kesehatan didominasi oleh kendala yang bersifat pribadi. Hambatan yang dirasakan merupakan unsur penentu terjadi perubahan perilaku atau tidak. ${ }^{9}$ Menurut 9 persepsi hambatan merupakan aspek negatif dari suatu perilaku sehat, dapat berupa tindakan yang menghalangi untuk berperilaku sehat, semacam bawah sadar, analisis biaya-manfaat, dimana seseorang mempertimbangkan manfaat yang diharapkan dari suatu tindakan dengan barrier (halangan) yang dirasakan. Misalnya, tindakan ini berguna namun mahal, mempunyai efek samping, tidak menyenangkan, atau memakan waktu. Penelitian 11 menyatakan bahwa subyek peneliti tidak melakukan praktik vaginal douching dengan alasan menganggap bahwa vaginal douching tidak selalu memberikan efek segar dan bersih, memberikan efek yang buruk pada organ kewanitaan, tidak di anjurkan oleh agama, dan tidak mengurangi resiko infeksi. ${ }^{11}$

Hal itu bisa disebabkan karena makin maraknya produk vaginal douching di masyarakat umum dikenal sebagai sabun pembersih kewanitaan atau sabun vagina yang dijual bebas dalam berbagai bentuk kemasan. Tidak semua produk pembersih vagina aman untuk digunakan. Mencuci vagina (douching) sering dikaitkan dengan keluhan disuria, keputihan, dan gatal pada vagina. Wanita yang 
beberapa kali melakukan douching, dilaporkan terjadi perubahan $\mathrm{pH}$ vagina dan konsentrasi mikroflora normal berkurang sehingga memungkinkan terjadinya pertumbuhan bakteri patogen yang oportunistik. ${ }^{16,18}$ Vaginal douching seringkali dikaitkan dengan terjadinya BV. Penggunaan vaginal douching dapat mengganggu ekosistem flora normal vagina dan penghentian penggunaan vaginal douching dapat menurunkan risiko terjadinya BV. ${ }^{4,16}$

Penggunaan alat kontrasepsi bukan lagi hal yang baru bagi masyarakat Indonesia. Tingginya angka kelahiran dan angka kematian Ibu di Indonesia menyebabkan Pemerintah turun tangan dengan penyelenggaraan program Dua Anak lebih Baik. Untuk mensukseskan program tersebut, maka sekarang akan mudah menemukan Dokter layanan primer yang dapat memberikan program layanan Keluarga Berencana atau biasa disingkat KB. KB memiliki beragam macam alat kontrasepsi yang dapat digunakan oleh wanita dan pria pada usia subur. Namun, pada survey yang dilakukan di Indonesia alat kontrasepsi lebih sering digunakan oleh wanita. Ada beberapa alat kontrasepsi wanita yang ada di Indonesia seperti KB hormonal (suntik, pil, implan), Intra uterine device (IUD), masektomi, diafragma, dan lain sebagainya. Bersadarkan survei Badan Kependudukan dan Keluarga Berencana (BKKBN) 2014 didapatkan hasil dimana KB hormonal merupakan jenis kontrasepsi yang paling digemari dengan presentase $84,39 \%$ dengan rincian pil 26,60\%, suntik 48,56\%, dan implasn 9,23\%.Bersadarkan survei tersebut juga didapatkan hasil bahwa pengguna KB di provinsi Jawa Barat mencapai 15,37\%. ${ }^{5}$

Hasil dari penelitian ini tidak sejalan dengan hasil penelitian yang dilakukaboleh Bradsaw et al yang menyatakan bahwa penggunaan kontrasepsi hormonal terutama jenis estrogen dapat meningkatkan kejadian BV. ${ }^{4}$ Namun hasil ini sesuai dengan hasil penelitian yang dilakukan oleh Vodstrcil et al yang menyebutkan bahwa tidak terdapat hubungan antara terjadinya BV dengan penggunaan kontrasepsi hormonal. ${ }^{5}$ Pada landasan teori disebutkan bahwa adanya kadar estrogen pada wanita menyebabkan kondisi $\mathrm{pH}$ vagina menjadi asam sehingga mempengaruhi jumlah flora normal vagina yaitu Lactobacillus sp. dalam jumlah yang sesuai sehingga dapat melawan bakteri-bakteri kontaminan yang menyerang vagina. ${ }^{6}$ Pada pengguna kontrasepsi dengan jenis progestin yang merupakan sistesis dari progesteron juga didapatkan hasil yang tidak bermakna. Progestin ini sering digunakan pada kontrasepsi hormonal jenis implan dan suntik. Penggunaan kontrasepsi yang menggunakan sintesis dari progesteron maka akan sering didapati efek samping berupa penurunan frekuensi siklus mestruasi. ${ }^{7}$ Selain itu tingginya konsentrasi progesteron menyebabkan penurunan hormon estrogen sehingga hal ini bisa saja menyebabkan kejadian BV pada pengguna kontrasepsi jenis ini meningkat. Namun hal ini tidak sejalan dengan hasil penelitian yang dilakukan oleh Vodstrcil et al yang mengatakan bahwa Jurnal Penelitian Kesehatan STIKes Dharma Husada Bandung 
menurununnya frekuensi menstruasi berbanding lurus dengan menurunnya resiko terjadinya BV pada wanita. Pada beberapa penelitian yang dibahas oleh Vodstrcil et al disebutkan bahwa kejadian BV meningkat pada siklus awal menstruasi dimana kadar estradiol dalam kondisi yang sangat rendah. Hal ini dikarenakan jumlah hemoglobin dalam saluran genital meningkat. Di dalam hemoglobin terdapat zat besi yang cukup tinggi. Zat besi inilah yang menjadi zat yang sangat penting untuk pertumbuhan Gradnella vaginalis yang merupakan bakteri anaerob tertinggi penyebab terjadinya $\mathrm{BV}{ }^{5}$

Tingginya penggunaan kontrasepsi hormonal jenis suntik disebabkan oleh proses penyuntikan yang hanya dilakukan setiap tiga bulan sekali sehingga menyebabkan pengguna merasa lebih nyaman dan tidak perlu khawatir akan terjadinya kehamilan. Kemudian dari 51 pengguna kontrasepsi hormonal tersebut terdapat 13 orang pengguna pil kontrasepsi yang atau sekitar 25,5\% dimana 10 dari pengguna tersebut dinyatakan positif menderita BV. Lalu didapatkan hasil bahwa 3 dari 4 orang pengguna kontrasepsi jenis implan merupakan penderita $\mathrm{BV}$.

\section{KESIMPULAN DAN SARAN}

Tidak ada pengaruh antara kebiasaan merokok terhadap kejadian $\mathrm{BV}$, namun terdapat pengaruh pada aktivitas seksual, penggunaan cairan pencuci vagina dan penggunaan alat kontrasepsi terhadap kejadian BV pada wanita usia subur. Diharapkan kepada seluruh wanita usia subur dapat mengetahui kondisi daerah kewanitaan terutama dengan keputihan yang tidak normal, dan dapat segera memeriksakan keadaanya ke tempat pelayanan kesehatan secara rutin terutama yang mempunyai faktor risiko. Bagi petugas kesehatan diharapkan dapat mengetahui secara dini risiko terjadinya BV pada wanita usia dini agar bisa dapat segera tertangani dan diobati.

\section{DAFTAR PUSTAKA}

1. Umbara PJA. Hubungan antara Derajat Vaginosis Bakterial Sesuai Kriteria Nugent dengan Partus Prematurus Iminen. Program Pendidikan Dokter Spesialis I Obstetri dan Ginecologi. Semarang: Universitas Diponegoro, 2009.

2. Pratiwi EN. Prevalensi dan Karakteristik Wanita Hamil Penderita Bacterial Vaginosis di Poliklinik Obstetri dan Ginekologi RSUD Arifin Achmad Pekanbaru 2012.

3. Sylvia Y.Muliawan JES. Diagnosis praktis vaginosis bakterial pada kehamilan. J Kedokteran Trisakti 2001;20(2):74 - 8.

4. Udayalaxmi GB, Subbannayya Kotigadde, Shalini Shenoy. Comparison of the Methods of Diagnosis of Bacterial Vaginosis. Journal of Clinical and Diagnostic Research 2011 June;5(3):498-501.

5. Filho DSC. Bacterial vaginosis: clinical, epidemiologic and microbiological features. HU Revista, Juiz de Fora, 2010;36(3):22330.

6. Buku Ajar Mikrobiologi Kedokteran. Jakarta: Binarupa Aksara 1994.

7. Ilmu Penyakit Kulit dan Kelamin, 1st ed. Jakarta: Balai Penerbit Fakultas Kedokteran Universitas Indonesia 1987; 311-6.

8. Tamonud Modak PA, Charan Agnes, Raja Ray, Sebanti Goswami, Pramit Ghosh, Nilay Kanti Das. Diagnosis of bacterial vaginosis in cases of abnormal vaginal discharge: comparison of clinical and microbiological criteria. J Infect Dev Ctries 2011;5(5):353-60. 
9. Bacterial Vaginosis. In: King K. Holmes M, $\mathrm{PhD}$, ed. Sexually Transmited Diseases, 3rd ed: McGraw-Hill, 1999.

10.Ningrat FS. Uji Sensitivitas dan Spesitifitas Autobio BV Assay dan kriteria Amsel Dibandingkan dengan Skor Nugent pada Vaginosis Bakterial Bag/SMF Ilmu Kesehatan Kulit dan Kelamin Semarang: Universitas Diponegoro, 2011; v. PPDS1.

11.Sexually Transmited Diseases (STDs): Bacterial Vaginosis (BV) Statistic. In: Koumans EH SM, Bruce C, McQuillan G, Kendrick J, Sutton M, Markowitz LE, ed. 1600 Clifton Rd. Atlanta, GA 30333, USA: Centers for Disease Control and Prevention (CDC), 2004; v. 2014.

12.Anggarawati D. Studi Prevalensi dan Keberhasilan Terapi Vaginosis Bakterialis pada Ibu Hamil. Obstetri dan Ginekologi. Semarang: Universitas Diponegoro, 2003.

13.Eschenbach DA, Hillier S, Critchlow C, et al. Diagnosis and clinical manifestations of bacterial vaginosis. Am J Obstet Gynecol 1988;158(4):819-28.

14.Gonzalez-Pedraza Aviles A, Mota Vazquez R, Ortiz Zaragoza C, Ponce Rosas RE. [Factors of risk of bacterial vaginosis]. Aten Primaria 2004;34(7):360-5.

15.Octaviany D. Risk Factors for Bacterial Vaginosis among Indonesia Women Med J Indones 2010;19:130-5.

16.Munjoma MW. Simple Method for The Detection of BActerial Vaginosis in Pregnant Women. Department of General Practice and Community Medicine. Oslo, Norwegia: University of Oslo, 2004.

17.Goyal R. Diagnosis of Bacterial Vaginosis in Women in Labour. JK Science 2005;7(1):1-4.

18.Hamilton GMC. Obstetri dan ginekologi Panduan praktis: Egc. 